The Labore Journal of Economics

$10: 1$ (Summer 2005) pp. 33-47

\title{
Explaining Financial Crises in Emerging Markets: A logit model on the Turkish data (1984-2001)
}

\section{Mete Feridun}

\section{Abstract}

This article aims at explaining the financial crises Turkey experienced in the last decade through a random effects logit model which incorporates 26 macroeconomic, political, and financial sector variables. Evidence emerges that the only significant variables are current account/GDP, fiscal balance/GDP, GDP per capita, national savings growth, foreign exchange reserves, terms of trade, stock prices, and import growth. Results indicate that all variables have expected signs with the exception of import growth.

Keywords: Logit models, financial crises, currency crises, emerging markets

\section{Introduction}

The Turkish economy was shaken by two devastating financial crises in the last decade. The first one coincides with a managed floating exchange rate regime whereas the latter, which had more severe effects than that of the first one, occurred in the midst of a stabilization program, which involved a crawling peg exchange rate regime.

Following the liberalization of the finance sector in the late 1980s, Turkey had attracted capital inflows due to high real interest rates. This led to an overvaluation of the Turkish lira. The appreciation of the currency and also the tariff reductions in 1989 caused current account deficits. The pressures on the exchange rate and the interest rates, and the open position of the banking system, which was around 5 billion dollars, increased the demand for dollars. At the end of 1993, public sector debt stock and deficits as a percentage of GDP reached record high levels and the burden of interest payments increased. The government attempted not to impede growth prior to the local election of the governments in March 1994 and it

\footnotetext{
* Lecturer in Economics and Business, Faculty of Economics \& Administrative Studies, Cyprus International University Nicosia, Cyprus. e-mail: mete.feridun@lycos.com
} 
made an attempt to control the interest rates. So, there was a policy shift from bond-finance to money-finance starting from the last months of 1993. Several Treasury bill auctions were cancelled and the Treasury started to rely on short-term advances from the Central Bank. Therefore, there was a substantial real increase in the Central Bank's domestic credits starting from the beginning of September 1993 (Akyuz and Boratav, 2002). The real return on Treasury bills turned to negative at the end of 1993. The cancellation of auctions increased the uncertainty in the financial markets and shook the confidence of investors. Finally the Treasury lost its ability to borrow.

Turkey followed a managed floating exchange rate regime until the end of 1999. In January 2000, Turkey signed a stand-by agreement with the IMF and began following a stabilization program, which involved implementing a crawling peg against a dollar-German mark basket, which allowed the exchange rate to fluctuate within a band. The uniqueness of this crawling peg exchange rate regime was that both the exit strategy and the date of exit were publicly known at the beginning of the program: the exchange rate would be allowed to fluctuate in a continuously widening band after eighteen months. Due to the fixed exchange rate policy, when the US dollar became overvalued, the Turkish Lira became overvalued as well, making exports expensive and imports cheap. This in turn, increased Turkey's trade deficit, interest rates, level of unemployment, and diminished its national production. Consequently, the country experienced a financial crisis on February 23, 2001, just four months before the exit day, triggered by an argument between Prime Minister Bulent Ecevit and President Ahmet Necdet Sezer over how to fight public-sector corruption, and had to give up its anchored exchange rate policy with an immense devaluation of $50 \%$ of the Turkish Lira, a huge decline in foreign exchange reserves of the Central Bank.

This article aims at explaining the financial crises Turkey experienced in the last decade through a random effects logit model which incorporates 26 macroeconomic, political, and financial sector variables. The paper is structured as follows. The next section provides an overview of the literature. Section III introduces the data and the methodology. Section IV presents the findings, and Section $\mathrm{V}$ points out the conclusions that emerge from the study.

\section{Literature Review}

Literature on financial crises is categorized into three mainstream models, namely first-generation models, second-generation models, and thirdgeneration models. In the "first-generation" models (Krugman 1979; Flood and Garber 1984), a government with persistent money-financed budget deficits is assumed to use a limited stock of reserves to peg its exchange rate and the 
attempts of investors to anticipate the inevitable collapse generates a speculative attack on the currency when reserves fall to some critical level.

In 'second-generation' models (Obstfeld 1994, 1996, Ozkan and Sutherland 1995, Radelet and Sachs 1998) policy is less mechanical: a government chooses whether or not to defend a pegged exchange rate by making a tradeoff between short-run macroeconomic flexibility and longerterm credibility. The crisis then arises from the fact that defending parity is more expensive as it requires higher interest rates. Should the market believe that defense will ultimately fail, a speculative attack on a currency develops either as a result of a predicted future deterioration in macro fundamentals, or purely through self-fulfilling prediction.

The need for third generation models became apparent in the 1990s with the Mexican Tequila crisis of 1994 and the East Asian crisis of 1997. A number of new approaches have emerged to explain how these crises evolved and how they spread from country to country. Third-generation models (Dooley 1997, Krugman 1998, Radelet and Sachs 1998) are categorized into three different groups such as herd-behavior, contagion, and moral hazard.

There have been numerous studies in the literature on early warning systems (EWS) of financial crises. Although studies differ in terms of the econometric method followed, variables employed, definition of financial crisis, and the time span on which the EWS is built, the literature can conveniently be categorized into two main groups. The first group consists of studies based on a model known as Signals Approach, which involves observing the behavior of a number of indicators as they issue signals when they exceed certain threshold values. The second approach is based on a logit or probit model and uses lagged values of early warning indicators and a crisis dummy variable designed to predict crises.

Signals approach was developed by Kaminsky et al. (1998) and consists of a bilateral model where a set of high frequency economic variables during a specified period is compared, one at a time, with a crisis index so that when one of these variables deviates from its normal level beyond a specific threshold value prior to a crisis, it issues binary signals for a possible currency crisis. The model devised by Kaminsky et al. (1998) consists of 15 variables with optimal thresholds estimated for each country in relation to percentiles of the distribution of observations of the indicator maximizing the correct signals and minimizing the false ones. They set their signal horizon at 24 months and defined a currency crisis as a sharp depreciation of the currency or a large decline in international reserves that exceeds the mean by more than three standard deviations. The percentage of correct signals to the 
percentage of false signals, on the other hand, gives an indication of the accuracy of each indicator. They used monthly data of 15 developing and 5 industrial countries from 1970 to 1995 and detected an average of 61 crises during this period. Their best indicators, based on noise-to-signal ratio, are real exchange rate, banking crises dummy, exports, stock prices, and M2/international reserves. This model was later improved by Kaminsky and Reinhart (1999), who used the same sample as in Kaminsky et al. (1998). Their model identified a total of 26 banking and 76 currency crises, 18 of which were twin crises. They found that the occurrence of both types of crises has increased sharply since the early 1980s with only one twin crisis taking place before 1980. In their study Kaminsky and Reinhart (1999) also found out that banking and currency crises had common causes with the former usually preceding the latter and following a particular pattern where the peaks of banking crises follows the currency crises.

Probit and logit models, pioneered by Frankel and Rose (1996), use limited dependent variable models known as probit or logit regressions to identify the causes of crises and to predict future crises. This approach defines a crisis indicator equal to one or zero depending on whether a currency crisis does or does not occur within the specified time period. Frankel and Rose (1996) attempted to find out how international debt structure and external factors affected the probability of currency crises. They used a number of external, internal and foreign macroeconomic variables in a multivariate probit model specified for 105 developing countries, covering annual data from 1971 to 1992 . They defined a crisis as at least $25 \%$ depreciation of the nominal exchange rate that also exceeds the previous year's depreciation level by at least $10 \%$ and constructed a dummy crisis variable according to that rule. Results of their model indicate that the significant variables are output growth, foreign direct investment/total debt, reserves, domestic credit growth, external debt and foreign interest rates.

Sachs, Tornell and Velasco (1996) also used a probit model to analyze currency crises, particularly the Mexican Tequila Crisis of 1995, using a sample of 20 emerging countries that were vulnerable to the contagion effect. They used the weighted sum of the percent decrease in reserves and the percent depreciation of the exchange rate as their crisis index. They found that crises happened only in the countries with weak fundamentals such as low reserves, fragile banking systems and overvalued exchange rate. They also found evidence showing that short-term capital inflows do not matter when reserves and fundamentals are strong whilst government consumption and current account deficits matter only in the countries with weak fundamentals and weak reserves. 
Berg and Pattillo (1999) tested models offered by Kaminsky, Lizondo and Reinhart (1998), Frankel and Rose (1996) and Sachs, Tornell, Velasco (1996) to see if these models could predict the Asian Crisis using information available at the end of 1996. They found that the models offered by Sachs, Tornell, Velasco (1996) and Frankel and Rose (1996) were ineffective in forecasting the Asian Crisis. The Kaminsky, Lizondo and Reinhart (1998) mode1, on the other hand, proved to be successfu1. Crisis probabilities generated by this model for the period between May 1995 and December 1996 were statistically significant predictors of actual crisis occurrence over the following 24 months. Berg and Pattillo (1999) also found that in all three approaches, the probability of a currency crisis increases when domestic credit growth is high, the real exchange rate is overvalued relative to trend, and the ratio of M2 to reserves is high.

In a recent study, Komulainen and Lukkarila (2003) examined the causes of financial crises in 31 emerging market countries during 1980-2001 using a probit model based on 23 variables. Their findings show that financial crises occur together with banking crises and an increase in private sector liabilities, public debt, foreign liabilities of banks, unemployment, inflation, and US interest rates raises the probability of a crisis. Table 1 summarizes the empirical literature on financial crises.

\section{Data and Methodology}

The logit model is estimated for a set of 26 macroeconomic, political, and financial sector variables spanning the period 1984:1 - 2001:2. Most data are gathered from DataStream, International Financial Statistics (IFS), and Turkish State Planning Organization database. The data for government debt figures come from several sources, including DataStream, IFS, the World Bank's WDI and IMF country reports. All data are transformed into natural logarithms in order to achieve mean reverting properties and to make statistical testing procedures valid. Indicators are selected on the basis of currency crisis theories and previous empirical literature. In addition to the traditional macroeconomic variables, we include several indicators describing the vulnerability of domestic banks. These indicators include the growth of bank deposits, the ratio of the lending rate to the deposit rate, and the ratio of bank reserves to assets. We also employ variables that indicate vulnerability to a sudden stop of capital inflows. These variables are public debt, broad money to reserves, and private sector liabilities. To study foreign influences on crises, we include the US interest rate. Besides, several political factors, namely the number of political parties in the government, left-wing dummy, central bank governor turnover, and a dummy variable for the timing of elections, are used. Since we study all these variables simultaneously, we hope to distinguish those indicators that 
reflect actual causes of the recent crises in Turkey. Table 2 shows the explanatory variables.

Table-1: Literature Review on Financial Crises

\begin{tabular}{|c|c|c|c|c|c|c|}
\hline tudy & $\begin{array}{l}\text { Kaminsky, } \\
\text { Lizondo, } \\
\text { Reinhart } \\
(1998)\end{array}$ & $\begin{array}{l}\text { Sachs. } \\
\text { Torne11, } \\
\text { Velasco } \\
\text { (1996) }\end{array}$ & $\begin{array}{l}\text { Kaminsky, } \\
\text { Reinhart } \\
\text { (1999) }\end{array}$ & $\begin{array}{l}\text { Berg, } \\
\text { Patillo } \\
(1999)\end{array}$ & $\begin{array}{l}\text { Frankel, } \\
\text { Rose (1996) }\end{array}$ & $\begin{array}{l}\text { Komulainen } \\
\text { and } \\
\text { Lukkarila } \\
(2003)\end{array}$ \\
\hline Approach & $\begin{array}{l}\text { Signals } \\
\text { approach }\end{array}$ & $\begin{array}{l}\text { Probit } \\
\text { model }\end{array}$ & $\begin{array}{l}\text { Signals } \\
\text { approach }\end{array}$ & $\begin{array}{l}\text { Both } \\
\text { approaches }\end{array}$ & $\begin{array}{l}\text { Probit } \\
\text { Mode1 }\end{array}$ & $\begin{array}{l}\text { Probit } \\
\text { Mode1 }\end{array}$ \\
\hline ata & $\begin{array}{l}1970-1975 \\
\text { monthly } \\
\text { data from } \\
15 \\
\text { developing } \\
\text { and } 5 \\
\text { industrial } \\
\text { countries }\end{array}$ & $\begin{array}{l}\text { Monthly } \\
\text { data from } \\
20 \\
\text { emerging } \\
\text { markets. }\end{array}$ & $\begin{array}{l}\text { Same } \\
\text { sample as } \\
\text { Kaminsky, } \\
\text { Lizondo, } \\
\text { Reinhart } \\
\text { (1998) }\end{array}$ & $\begin{array}{l}\text { Same } \\
\text { variables as } \\
\text { Kaminsky, } \\
\text { Lizondo, } \\
\text { Reinhart } \\
\text { (1998) plus } \\
\text { M2/reserve } \\
\text { s and CA/ } \\
\text { GDP }\end{array}$ & $\begin{array}{l}1971-1992 \\
\text { annual data } \\
\text { from } 105 \\
\text { developing } \\
\text { countries }\end{array}$ & $\begin{array}{l}1980-2001 \\
\text { monthly } \\
\text { data from } \\
31 \text { emerging } \\
\text { and } \\
\text { developing } \\
\text { countries }\end{array}$ \\
\hline $\begin{array}{l}\text { Crisis } \\
\text { Index }\end{array}$ & $\begin{array}{l}\text { Weighted } \\
\text { average of } \\
\text { exchange } \\
\text { rate and } \\
\text { reserve } \\
\text { changes } \\
\text { with a } \\
\text { threshold } \\
\text { of mean } \\
+3 \\
\text { standard } \\
\text { deviation. }\end{array}$ & $\begin{array}{l}\text { Weighted } \\
\text { sum of } \\
\text { percent } \\
\text { decrease in } \\
\text { reserves } \\
\text { and the } \\
\text { percent } \\
\text { depreciatio } \\
\mathrm{n} \text { of the } \\
\text { exchange } \\
\text { rates }\end{array}$ & $\begin{array}{l}\text { Weighted } \\
\text { average of } \\
\text { exchange } \\
\text { rate } \\
\text { changes } \\
\text { and } \\
\text { reserves }\end{array}$ & $\begin{array}{l}\text { Same as } \\
\text { Kaminsky, } \\
\text { Lizondo, } \\
\text { Reinhart } \\
\text { (1998) }\end{array}$ & $\begin{array}{l}\text { Exchange } \\
\text { rate change } \\
\text { over } 25 \% \text {, } \\
\text { at least } 10 \% \\
\text { higher than } \\
\text { previous } \\
\text { year }\end{array}$ & $\begin{array}{l}\text { Equally } \\
\text { weighted } \\
\text { exchange } \\
\text { rate } \\
\text { depreciation } \\
\text { and loss of } \\
\text { reserves } \\
\text { with a } \\
\text { threshold of } \\
+2 \text { standard } \\
\text { deviations }\end{array}$ \\
\hline $\begin{array}{l}\text { Significant } \\
\text { Variables }\end{array}$ & $\begin{array}{l}\text { Real } \\
\text { exchange } \\
\text { rate, } \\
\text { exports, } \\
\text { banking } \\
\text { crises } \\
\text { dummy, } \\
\text { stock } \\
\text { prices, } \\
\text { M2/interna } \\
\text { tional } \\
\text { reserves }\end{array}$ & $\begin{array}{l}\text { Low } \\
\text { reserves, } \\
\text { fragile } \\
\text { banking } \\
\text { systems, } \\
\text { overvalued } \\
\text { exchange } \\
\text { rate }\end{array}$ & $\begin{array}{l}\text { Banking } \\
\text { and } \\
\text { currency } \\
\text { crises have } \\
\text { common } \\
\text { causes }\end{array}$ & $\begin{array}{l}\text { Real } \\
\text { exchange } \\
\text { rate, } \\
\text { current } \\
\text { account, } \\
\text { reserve, } \\
\text { export, } \\
\text { and M2/ } \\
\text { reserves }\end{array}$ & $\begin{array}{l}\text { Output } \\
\text { growth, } \\
\text { foreign } \\
\text { direct } \\
\text { investment/ } \\
\text { total debt, } \\
\text { reserves, } \\
\text { domestic } \\
\text { credit } \\
\text { growth, } \\
\text { external } \\
\text { debt and }\end{array}$ & $\begin{array}{l}\text { Private } \\
\text { sector } \\
\text { liabilities, } \\
\text { public debt, } \\
\text { foreign } \\
\text { liabilities of } \\
\text { banks, } \\
\text { unemploym } \\
\text { ent, } \\
\text { inflation, } \\
\text { and US } \\
\text { interest }\end{array}$ \\
\hline
\end{tabular}




\begin{tabular}{lll}
\hline foreign rates \\
interest \\
rates
\end{tabular}

Table-2: Explanatory Variables

\begin{tabular}{|c|c|}
\hline $\begin{array}{r}\text { Indicator \& } \\
\text { Expected Sig1 }\end{array}$ & Explanation \\
\hline Inflation & $\begin{array}{l}+ \text { Inflation is associated with high nominal interest rates } \\
\text { and may proxy macroeconomic mismanagement that } \\
\text { adversely affects the economy and the banking system } \\
\text { (Demirguc-Kunt and Detragiache 1997). Countries } \\
\text { whose inflation rates diverge from those of the anchor } \\
\text { countries will find it difficult to maintain currency } \\
\text { stability over extended periods of time. One-month } \\
\text { lagged inflation is used, as current inflation will be } \\
\text { affected by devaluations through rising import prices. }\end{array}$ \\
\hline $\begin{array}{l}\text { Real Exchange } \\
\text { Rate }\end{array}$ & $\begin{array}{l}\text { - Currency overvaluation may lead to deteriorations in the } \\
\text { current account and have historically been associated } \\
\text { with currency crises (Berg and Patillo,. 1999). }\end{array}$ \\
\hline $\begin{array}{l}\text { Export } \\
\text { Growth }\end{array}$ & $\begin{array}{l}\text { Weak exports may lead to deteriorations in the current } \\
\text { account and have often been associated with currency } \\
\text { crises (Dowling and Zhuang, 2000). }\end{array}$ \\
\hline $\begin{array}{l}\text { Import } \\
\text { Growth }\end{array}$ & $\begin{array}{l}\text { Excessive import growth could lead to worsening in the } \\
\text { current account and have been related with currency } \\
\text { crises (Berg and Patillo 1999) }\end{array}$ \\
\hline M1 & $\begin{array}{l}\text { + Growth of M1 indicates excess liquidity, which may } \\
\text { invoke speculative attacks on the currency thus leading } \\
\text { to a currency crisis (Eichengreen et al. 1995). }\end{array}$ \\
\hline $\begin{array}{l}\text { Domestic } \\
\text { Credit/GDP }\end{array}$ & $\begin{array}{l}+ \text { High levels of domestic credit indicate the fragility of a } \\
\text { banking system (Kaminsky and Reinhart, 1998). }\end{array}$ \\
\hline Stock Prices & $\begin{array}{l}\text { - Recessions and a burst in asset price bubbles often } \\
\text { precede currency crises (Kaminsky and Reinhart, 1999). }\end{array}$ \\
\hline $\begin{array}{l}\text { Terms of } \\
\text { Trade }\end{array}$ & $\begin{array}{l}\text { - Increases in terms of trade strengthen a country's } \\
\text { balance of payments position and lower the probability } \\
\text { of a crisis (Kaminsky et al. 1998). }\end{array}$ \\
\hline
\end{tabular}



Public + Higher indebtedness is expected to raise vulnerability to Debt/GDP a reversal in capital inflows, and hence to raise the probability of a crisis (Lanoie and Lemarbre, 1996).
Foreign direct + Shows net inflows in the reporting economy. East Asian investment/ countries had been dependent on net capital inflows GDP over the decade preceding the crisis
US Interest + International interest rate increases are often associated rates with capital outflows (Edison, 2003)
Bank Reserves/ - Shows the liquidity of the banking system. Adverse Bank Assets macroeconomic shocks are less likely to lead to crises in countries where the banking system is liquid (Demirguc-Kunt and Detragiache, 1997).

Financial - Broad money as a ratio of GDP is commonly used to development measure the level of a country's financial development. In financially underdeveloped countries a large component of broad money is currency held outside the banking system. We use (M3-M1)/GDP to exclude currency in circulation from the broad money stock (Demetriades and Hussain, 1996).

Real interest + Used as a proxy of financial liberalization. Liberalization rate process itself tends to lead to high real rates. High real interest rates have been increased to repel a speculative attack (Kaminsky et al. 1998).

Foreign - Most currency collapses are preceded by a period of exchange increased efforts to defend the exchange rate, which are reserves marked by declining foreign exchange reserves (Kaminsky et al. 1998).

Banking crisis + Banking and currency crises tend to occur simultaneously dummy (Kaminsky and Reinhart, 1998) A dummy variable was used taking the value 1 if there was a banking crisis starting or ongoing within the previous six months.

Lending Rate- + An increase of this indicator reflects a deterioration in Deposit Rate credit risk as banks are unwilling to lend or decline in loan equity (Kaminsky et al. 1998) 
Current Account/GDP

M2/Foreign Exchange reserves

Fiscal Balance/GDP

Number of Political Parties

Elections
- An increase in the current account is associated with large capital inflows which indicate a diminished probability to devalue and thus to lower the probability of a crisis (Berg and Patillo 1999). Large current account deficit (lagged) may indicate a need to devalue to achieve external balance. One-month lagged variable is used, as the cost of imports increases and export revenues decrease immediately after the devaluation event, as part of the J-curve effect.

+ Indicates to what extent the liabilities of the banking system are backed by foreign reserves. It also captures the ability of the central bank to meet sudden domestic foreign exchange demands (Berg and Patillo 1999).

+ Higher fiscal deficits are expected to raise the probability of crisis since they increase the vulnerability to shocks and investor's confidence. Besides, large deficits may indicate a need for seigniorage finance, which endangers the peg. (Demirguc-Kunt and Detragiache, 1997).

+ Represents the number of political parties forming a government. The least stable form of government under deteriorating economic conditions is a multi-party coalition, as under economic pressure individual parties tend to withdraw from the coalition agreement for fear of being associated with economic mismanagement. It takes the value of zero for dictatorial systems, one for single-party government, two for two-party coalition government, three for three-party coalition government, and so on.

+ A government is less likely to undertake politically costly defense of the exchange rate and is more likely to use monetary and exchange rate policy to boost employment when they face an election. Besides, frequent elections restrain the governments from fiscal austerity, and correcting external misalignments. The dummy consists of a dummy variable used to capture the effects of elections on the likelihood of a crisis. It assumes the value of one in the six months preceding the elections, including the election month. 
Central bank + Used as a proxy for the independence of the central governor bank. If governors are easily replaced then they are less turnover likely to pursue policies that are disadvantageous to the government. This is the average turnover rate of central bank governors in a two-year period. A high turnover indicates a low degree of central bank independence.

Left-wing dummy

+ Left wing governments are seen as more focused on internal objectives such as employment and growth, rather than external objectives (Simmons, 1994). The proxy takes the value 1 in each year a leftist party is in power, or in the coalition.

GDP per capita

- Deterioration of domestic economic activity is expected to increase the likelihood of crises (Lanoie and Lemarbre 1996).

National

- High national savings may be expected to lower the Saving Growth probability of debt rescheduling (Lanoie and Lemarbre 1996).

The dependent variable is determined based on the change in the $\log$ of the annual average Turkish lira - US dollar exchange rate. Since the Turkish lira devalued every year during the last two decades, a random effects logit is estimated in this study. For each month, we observe the binary dependent variable $\mathrm{Y}$ :

$$
Y=\left\{\begin{array}{lll}
1 & \text { with probability } & \operatorname{Pr}(Y=1)=P \\
0 & \text { with probability } & \operatorname{Pr}(Y=0)=1-P
\end{array}\right.
$$

We explain the crisis index $\mathrm{Y}$ by a set of $\mathrm{K}$ independent variables $\mathrm{X}$. Hence $\mathrm{X}$ is a $\mathrm{KN} \times \mathrm{T}$ matrix of observations. The aim of the model is to estimate the effect of the indicators $\mathrm{X}$ on the probability $\mathrm{P}$ of experiencing a crisis $\mathrm{Y}$. We denote $\gamma$ as the vector of $\mathrm{K}$ marginal effects:

$$
\gamma=\frac{d P}{d X}
$$

In probit and logit models the probability of a crisis is a non-linear function of the indicators:

$$
\operatorname{Pr}(Y=1)=F(X \beta)
$$


Using a logistic distribution defines the logit model:

$$
\operatorname{Pr}(Y=1)=F(X \beta)=\frac{e^{\mathrm{x} \beta}}{1+e^{\mathrm{x} \beta}}
$$

In the logit model the effect of the indicators on the odds is then defined as:

$$
\Omega(Y=1 \mid X) \frac{P}{1-P}=e^{\mathrm{x} \beta}
$$

The effect of the indicators on the odds ratio, given two realizations of $\mathrm{X}$, e.g. $\mathrm{X}_{1}$ and $\mathrm{X}_{0}$, is:

$$
\frac{\Omega\left(Y=1 \mid X_{i}\right)}{\Omega\left(Y=1 \mid X_{o}\right)}=e^{\left(\mathrm{X}_{1}-\mathrm{X}_{2}\right) \beta}
$$

The odds ratio shows how the odds of observing $\mathrm{Y}=1$ change when $\mathrm{X}$ moves from $\mathrm{X}_{1}$ to $\mathrm{X}_{0}$. The observed variable receives a value of 0 or 1 depending on whether a crisis has occurred or not. Since in currency crisis situations a successful attack leads to sharp currency depreciation and substantial reserve losses, both the signal approach and limited dependent models traditionally define a currency crisis as a discrete event. One common technique is to construct an index of exchange market pressure as a weighted average of exchange rate changes and reserves changes (as well as interest rates in some cases). The crisis is said to occur when the index exceeds a particular threshold level. At this point, we calculate an exchange market pressure index (EMP) for each country. The index includes exchange rate depreciation and loss of reserves, which are weighted to influence equally. The exchange market pressure index takes the form:

$$
\mathrm{EMP}=\Delta \mathrm{e}-\left(\sigma_{\mathrm{e}} / \sigma_{\mathrm{r}}\right) * \Delta \mathrm{r}
$$

where $\Delta \mathrm{e}$ denotes the change in exchange rate and $\Delta \mathrm{r}$ in international reserves, $\sigma_{\mathrm{e}}$ and $\sigma_{\mathrm{r}}$ denote the standard deviation of exchange rate alteration and reserves, respectively. We determine the values of the EMP index more than two standard deviations above the mean as a crisis. Since macroeconomic variables often worsen prior to the actual crisis, we define as a crisis not only the crisis month but also the eleven months before. In other words, we use a one-year window for our variables.

Table-3 presents the results of the regression. Strong evidence emerges that eight variables are significant in explaining the financial crises 
in Turkey in the last two decades. These variables are current account/GDP, fiscal balance/GDP, GDP per capita, national savings growth, foreign exchange reserves, terms of trade, stock prices and import growth, all with signs that are in line with our expectations except import growth which has a negative sign.

\section{Table-3: Logit Regression Results}

\begin{tabular}{|c|c|c|c|c|c|}
\hline Variable & Coefficient & Z-statistic & Variable & Coefficient & Z-statistic \\
\hline $\begin{array}{l}\text { Current } \\
\text { Account/GDP }\end{array}$ & -11.928427 & $2.49673^{* *}$ & Inflation & 12.72111 & 0.56732 \\
\hline $\begin{array}{l}\text { M2/Foreign } \\
\text { Exchange } \\
\text { reserves }\end{array}$ & 0.013242 & 0.05508 & $\begin{array}{l}\text { Real } \\
\text { Exchange } \\
\text { Rate }\end{array}$ & -13.23113 & 0.46155 \\
\hline $\begin{array}{l}\text { Fiscal } \\
\text { Balance/GDP }\end{array}$ & 3.87829 & $1.75243^{*}$ & $\begin{array}{l}\text { Export } \\
\text { Growth }\end{array}$ & -0.01231 & 0.75202 \\
\hline $\begin{array}{l}\text { Number of } \\
\text { Political } \\
\text { Parties }\end{array}$ & 0.04201 & 1.05024 & $\begin{array}{l}\text { Import } \\
\text { Growth }\end{array}$ & -0.04914 & $1.68047^{*}$ \\
\hline Elections & 12.021114 & 1.12038 & M1 & 12.04421 & 0.12033 \\
\hline $\begin{array}{l}\text { Central bank } \\
\text { governor } \\
\text { turnover }\end{array}$ & 22.89281 & 1.34422 & $\begin{array}{l}\text { Domestic } \\
\text { Credit/ GDP }\end{array}$ & 0.05142 & 0.03374 \\
\hline $\begin{array}{l}\text { Left-wing } \\
\text { dummy }\end{array}$ & 0.00121 & 1.01363 & Stock Prices & -23.14223 & $1.69363^{*}$ \\
\hline $\begin{array}{l}\text { GDP per } \\
\text { capita }\end{array}$ & -11.23222 & $-1.79552 *$ & $\begin{array}{l}\text { Terms of } \\
\text { Trade }\end{array}$ & -2.19395 & $3.29552^{* * *}$ \\
\hline $\begin{array}{l}\text { National } \\
\text { Saving } \\
\text { Growth }\end{array}$ & -22.32211 & $1.71380^{*}$ & $\begin{array}{l}\text { Public Debt/ } \\
\text { GDP }\end{array}$ & 0.09722 & 1.01330 \\
\hline $\begin{array}{l}\text { Real interest } \\
\text { rate }\end{array}$ & 12.62211 & 1.12038 & $\begin{array}{l}\text { Foreign } \\
\text { direct } \\
\text { investment/ } \\
\text { GDP }\end{array}$ & 0.06051 & 0.00991 \\
\hline $\begin{array}{l}\text { Foreign } \\
\text { exchange } \\
\text { reserves }\end{array}$ & -36.46514 & $2.53574^{* *}$ & $\begin{array}{l}\text { US Interest } \\
\text { rates }\end{array}$ & 0.05047 & -0.03234 \\
\hline $\begin{array}{l}\text { Banking crisis } \\
\text { dummy }\end{array}$ & 22.34222 & 1.01353 & $\begin{array}{l}\text { Bank } \\
\text { Reserves/ } \\
\text { Bank Assets }\end{array}$ & -0.02095 & -0.06231 \\
\hline $\begin{array}{l}\text { Lending } \\
\text { Rate-Deposit }\end{array}$ & 0.01953 & -0.25582 & $\begin{array}{l}\text { Financial } \\
\text { development }\end{array}$ & -7.10251 & 2.56732 \\
\hline
\end{tabular}


Rate

C $\quad 21.72221 \quad 1.713380$

* Significant at the $10 \%$ level.

** Significant at the $5 \%$ level.

*** Significant at the $1 \%$ leve1.

$\mathrm{C}$ is the intercept term

IV. Conclusions

In this study a random-effects logit model is built for Turkey using 26 macroeconomic, political, and financial sector variables. The logit model built in this study employs not only macroeconomic indicators but also qualitative variables such as banking crises, political variables, and central bank government turnover rate. Evidence emerges that the only significant variables are current account/GDP, fiscal balance/GDP, GDP per capita, national savings growth, foreign exchange reserves, terms of trade, stock prices, and import growth. Results indicate that all variables have expected signs with the exception of import growth. 


\section{References}

Akyuz, Yilmaz and Korkut Boratav 2002, "The Making of the Turkish Financial Crisis”, UNCTAD Discussion Paper Number 158.

Berg, Andrew and Catherine Pattillo 1999, "Predicting Currency Crises: The Indicators Approach and an Alternative", Journal of International Money and Finance, Vol. 18, No. 4, (August) pp. 561- 586.

Demetriades, P. O. and Hussein, K. A. 1996, "Does financial development cause economic growth? Time-series evidence from 16 countries." Journal of Development Economics, 51, 387-411.

Demirguc-Kunt, A. and E. Detragiachhe 1997, "The Determinants of Banking Crises in Developing and Developed Countries”, IMF Working Paper 106, IMF, Washington, D.C.

Dooley, M 1997, “A Model of Crisis in Emerging Markets”. NBER Working Paper Number 6300, Cambridge, MA.

Dowling, Malcolm and Juzhong Zhuang 2000, "Causes of the 1997 Asian Financial Crisis: What More Can We Learn from an Early Warning System Mode1?” Department of Economics, Melbourne University, Australia Working Paper. Number 123.

Edison, H. J. 2003, "Do indicators of financial crises work? An evaluation of an early warning system", International Journal of Finance and Economics, 8(1), 11-53.

Eichengreen, B., A.K. Rose, and C. Wyplosz. 1995, "Exchange Rate Mayhem: The Antecedents and Aftermath of Speculative Attacks", Economic Policy, Number 21.

Flood, R., and P. Garber 1984, "Collapsing Exchange Rate Regimes: Another Linear Examples.” Journal of International Economics, 41: 223-234.

Franke1, Jeffrey and Andrew Rose 1996, "Currency Crashes in Emerging Markets. An Empirical Treatment," Journal of International Economics, 41, November, 351-366.

Kaminsky, G., Lizondo, S., Reinhart, C. 1998, "Leading Indicators of Currency Crises”, IMF staff papers, Vol. 45, No 1. 
Kaminsky, G. L., and C.M. Reinhart 1998, "The Twin Crises: The Causes of Banking and Balance of Payments Problems”, American Economic Review, Vol. 89 (June) pp. 473-500

Komulainen, T. and J. Lukkarila 2003, "What Drives Financial Crises in Emerging Markets?, Emerging Markets Review, Vo1. 4: 248-272

Krugman, P. 1979, “A Model of Balance of Payments Crises”, Journal of Money, Credit, and Banking 11: 311-325.

Krugman, Paul, 1998, Bubble. Boom, Crash: Theoretical Notes on Asia's Crises (unpublished) Cambridge MA: MIT

Lanoie, P. and S. Lemarbre 1996, "Three approaches to predict the timing and quantity of LDC debt rescheduling”, Applied Economics, 28(2), 241- 246.

Obstfeld, Maurice 1994, “The Logic of Currency Crises” Cahiers Economiques et Monetaires (43): 189-213

1996, "Rational and Self-Fulfilling Balance of Payments Crises”, American Economic Review, Vol. 76 (March), pp. 72-81.

Ozkan, G. and A. Sutherland 1995, "Policy Measures to Avoid Currency Crisis.” Economic Journal, 105: 510-519.

Radelet, S. and J. Sachs 1998, "The East Asian Financial Crisis: Diagnosis, Remedies, Prospects”. Brookings Papers on Economic Activity, 1: $1-90$.

Sachs, J., A.Torne11, and A.Velasco 1996, "Financial Crises in Emerging Markets: The Lessons from 1995," Brookings Papers on Economic Activity pp. 147-218. 